$12-1-2000$

\title{
Irresolute Ravishers and the Sexual Economy of Chivalry in the Romantic Novel
}

Gary Dyer

Cleveland State University, g.dyer@csuohio.edu

Follow this and additional works at: https://engagedscholarship.csuohio.edu/cleng_facpub

Part of the Literature in English, British Isles Commons

How does access to this work benefit you? Let us know!

Publisher's Statement

Article originally published as Dyer, Gary, "Irresolute Ravishers and the Sexual Economy of

Chivalry in the Romantic Novel," Nineteenth-Century Literature, Vol. 55, No. 3 (Dec 2000): 340-68.

(c) 2000 by The University of California Press.

\section{Recommended Citation}

Dyer, Gary, "Irresolute Ravishers and the Sexual Economy of Chivalry in the Romantic Novel" (2000).

English Faculty Publications. 26.

https://engagedscholarship.csuohio.edu/cleng_facpub/26

This Article is brought to you for free and open access by the English Department at EngagedScholarship@CSU. It has been accepted for inclusion in English Faculty Publications by an authorized administrator of EngagedScholarship@CSU. For more information, please contact library.es@csuohio.edu. 


\title{
Irresolute Ravishers and the Sexual Economy of Chivalry in the Romantic Novel
}

\author{
GARY DYER
}

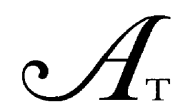

the climax of James Fenimore Cooper's The Last of the Mohicans (1826) the American Indian Magua, finding himself unable to kill his captive Cora Munro as he has threatened, looks at her with a facial expression "in which conflicting passions fiercely contended." 1 The situation here evokes the climax of Walter Scott's Ivanhoe, published seven years earlier, in which Rebecca is saved from being burned at the stake when the villain Brian de BoisGuilbert abruptly falls dead, overcome by "the violence of his own contending passions." 2 In this essay I explore how these historical novels from the Romantic period attempt to deal with the problems attendant on the chivalrous desire to defend women-chivalry that ultimately becomes inconsequential,

Nineteenth-Century Literature, Vol. 55, No. 3, pp. 340-368. ISSN: o891-9356.

(c) 2000 by The Regents of the University of California/Society. All rights reserved.

Send requests for permission to reprint to: Rights and Permissions, University of California Press, Journals Division, 20oo Center Street, Suite 303, Berkeley, CA 94704-1 223.

${ }^{1}$ James Fenimore Cooper, The Last of the Mohicans; A Narrative of I 757, ed. James A. Sappenfield and E. N. Feltskog (Albany: State Univ. of New York Press, 1983), p. 337. Further references are to this edition and are included in the text.

${ }^{2}$ Walter Scott, Ivanhoe, ed. Graham Tulloch, vol. 8 of The Edinburgh Edition of the Waverley Novels (Edinburgh: Edinburgh Univ. Press, 1984), p. 392. Further references are to this edition and are included in the text. 
since in each of the two climactic scenes the woman's fate hangs less on the intervention of a "knight" than on her own resolution and the irresolution of her oppressor. Although Cooper's novel echoes Scott's in many ways, it ultimately diverges in its view of chivalry.

By "chivalry" I mean something very specific: a standard for behavior, often professed to originate in the codes of medieval knighthood, that requires self-abrogation and self-sacrifice from a privileged man in defense of the powerless and disadvantaged, who are typically, even characteristically, women. It is chivalry in roughly this sense that writers from the Romantic period usually mean when they refer to the spirit of chivalry, as distinct from the specific forms that it took in the Middle Ages. ${ }^{3}$ I do not intend to critique the ideology of chivalry myself (few readers will need any help to do that). Instead, I want to investigate how this ideology is embodied, tested, and sometimes stretched beyond its breaking point by fictional narratives from a period when it was being reformulated as well as obliged to carry a great deal of cultural and political weight. In Ivanhoe and The Last of the Mohicans chivalry is thoroughly implicated in a form of patriarchal desire, even when practiced by the novels' heroes: it entails monopolizing the defense of women in order to serve men's interests. No one is surprised to read of men asserting that they and others like them (of their class, their nation, their race, and so on) are especially qualified or inclined to protect women, and it is axiomatic today that such claims

${ }^{3}$ This distinction was made frequently, by Walter Scott and by others. Joseph Phillimore wrote in a 1798 Oxford prize essay on the subject: "We have seen . . . the institutions, by which [chivalry] was propagated, cherished, and kept alive, fall to the ground-while the spirit still survives" ("Chivalry," in The Oxford English Prize Essays, 4 vols. [Oxford: D. A. Talboys, 183 o], II, 137). And Charles Mills wrote in his 1825 History of Chivalry: "This spirit, though not the form, of the chivalric times has survived to ours, and forms one of our graces and distinctions" (The History of Chivalry; or Knighthood and Its Times, 2 vols. [London: Longmans, 1825], II, 359). The interrelated meanings of "chivalry" range widely, and in reading works from this period we continually have to distinguish those instances where the word denotes ideology from those where it denotes institutions, and to ask whether it denotes something specific to the medieval period or more general. But when a person in the period intends "chivalry" to have one of these meanings, the others trail closely behind, and the question of protecting women is never far away. 
serve to legitimate their domination of women and of other men. What is intriguing nonetheless is how troubled, convoluted, and contradictory the fictional working-through of these claims can be.

In his Reflections on the Revolution in France (1790) Edmund Burke mourned that the "age of chivalry" was over, ${ }^{4}$ but his elegy in fact was a sign, even a catalyst, of chivalry's rebirth. Along with the revival of interest in the Middle Ages came admiration for medieval values, or at least values that were declared to be medieval. ${ }^{5}$ Burke's focus on transgressions against Marie Antoinette hinted at what was to be a crucial theme of this revival: prominent among chivalric principles, as Scott noted in 1817 , was "the general feeling of respect to the female sex." ${ }^{6}$ This kind of chivalry encompassed both sexual desire and its renunciation or sublimation: in a 1790 letter to Philip Francis, Burke attributed the best British and European manners to "the Chivalrous Spirit which dictated a veneration for Women of condition and of Beauty, without any consideration whatsoever of enjoying them."7 In Scott and Cooper's era, literature recuperated the ideology of chivalry in order to acknowledge injustices that women suffered (particularly sexual assault), but also to restrain or channel critique of those abuses.

${ }^{4}$ Reflections on the Revolution in France, ed. J.G.A. Pocock (Indianapolis: Hackett, 1987 ), p. 66.

${ }_{5}$ On chivalry as a contested term in the period, see David Duff, Romance and Revolution: Shelley and the Politics of a Genre (Cambridge: Cambridge Univ. Press, 1994), esp. pp. 30-43 and 115-53; see also Anna Clark, "Queen Caroline and the Sexual Politics of Popular Culture in London, 1820," Representations, no. 31 (1990), 53-54. Focusing on plebeian reaction against George IV's 1820 attempt to divorce Queen Caroline, Clark finds that "the limitations of chivalry were to be found on the level of gender, not class," insofar as this chivalry "entailed a portrayal of women as weak and in need of protection" (p. 54). For accounts of the revitalized medievalism in nineteenth-century Britain, see Alice Chandler, A Dream of Order: The Medieval Ideal in Nineteenth-Century English Literature (Lincoln: Univ. of Nebraska Press, 1970); and Mark Girouard, The Return to Camelot: Chivalry and the English Gentleman (New Haven: Yale Univ. Press, 1981).

${ }^{6}$ [Walter Scott], "Chivalry," in Supplement to the Fourth, Fifth, and Sixth Editions of the Encyclopcedia Britannica. With Preliminary Dissertations on the History of the Sciences (Edinburgh: Archibald Constable and Co., $1815^{-24}$ ), III, 144 .

7 Edmund Burke, letter to Philip Francis, 20 February 1790, in The Correspondence of Edmund Burke, ed. Alfred Cobban and Robert A. Smith, 1o vols. (Cambridge: Cambridge Univ. Press, 1958-78) VI, 9o-91. 
In The Last of the Mohicans, as in Ivanhoe, the action ultimately focuses on one man threatening a woman with violation, while another man tries to save her. In each novel the woman's chance to escape her would-be ravisher depends finally on the villain's failure of "resolution," as he is momentarily paralyzed when he finds that the heroine is "resolved" to die rather than suffer abuse. This failure is required because the chivalrous hero lacks the necessary strength or skill, and because the protection provided by the heroine's contrastingly strong "resolution" is temporary or partial at best.

But The Last of the Mohicans subverts this story pattern, which was established in Ivanhoe. In this novel, Scott's attraction to chivalric ideology must confront its inadequacies; for a skeptical reader, analyzing the "resolutions" in the novel serves to delegitimate the narrative resolution that results, one that the novel needs in order for its ideology to cohere. In The Last of the Mohicans these inadequacies are shown to be decisive and inescapable, as if to rebut Scott's unsuccessful attempt to recuperate the core of the chivalric tradition. The Last of the Mohicans in fact renders the earlier novel's struggles over chivalry moot, since one effect of Cooper's adopting certain contemporary stereotypes of Native American "savages" is to show that a worse problem than chivalry's inconsistencies and contradictions is its finitude: chivalry is not all-pervasive, and it is powerless when the men who threaten are outside its sexual economy. Viewing The Last of the Mohicans with this issue in mind, one suspects that if there had been no such discursive traditions concerning the Indian, Cooper would have invented them.

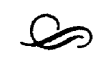

Ivanhoe and The Last of the Mohicans rework the familiar literary topos in which a nation or a social class is vindicated by its men's chivalrous defense of women. Scott and Cooper certainly knew numerous fictional narratives using this topos, and two of these works, Shakespeare's poem The Rape of Lucrece (1594) and Richardson's Clarissa (1747-48), demand special attention because, like Ivanhoe and The Last of the Mohi- 
cans, they each give a pivotal role to the villain's and the heroine's "resolution." ${ }^{\prime}$ In each of these works the heroine's moral strength cannot prevent her from being assaulted sexually, but it later brings her victory of another kind. The heroine dies resolutely, and her death inspires in men the chivalrous fortitude that enables them to punish her attacker.

In elaborating on the accounts provided by Livy and Ovid of the Roman matron Lucretia's fate, Shakespeare made the events hang on attributes like "will" and "resolution." As the king's son Sextus Tarquinius is planning to assault Lucrece, he assures himself that his "will is backed with resolution." ${ }^{9}$ Before stabbing herself Lucrece tells her husband to kill Tarquin, and she holds up her determination as a model for him in pursuing this vengeance: "My resolution, love, shall be thy boast, / By whose example thou revenged mayst be" (p. 200; 11. 1,193-94). Shakespeare endows this story with an anachronistic Christian and chivalric dimension, and Lucrece invokes chivalry when she demands revenge, telling her husband's companions that "Knights by their oaths should right poor ladies' harms" (p. 223; 1. 1,694). This kind of knighthood plays a decisive political role in Shakespeare's poem, insofar as it leads to the establishment of the Roman republic after years of tyranny.

Clarissa is even more prototypical for the "resolution" tradition, as we might expect in light of how it provided the threatened-woman motifs that run through much eighteenthand nineteenth-century literature, notably in the Gothic novel. After deciding to drug and assault Clarissa, Lovelace is troubled to find that "enervating pity unsteel[s] [his] foolish heart." 10 He needs "to keep up a resolution which the women about me will have it I shall be still unable to hold" (p. 879), and to that end he vows that he will concentrate on his reasons for raping

8 Scott's knowledge of Richardson was extensive. The central document is the account of Richardson that he wrote for Ballantyne's Novelist's Library: with Lives of the Authors (1821-24), in which he discusses Clarissa at length. See Walter Scott, Biographical Memoirs of Eminent Novelists, and Other Distinguished Persons, 2 vols. (1 834; rpt. Freeport, N.Y.: Books for Libraries Press, 1972), pp. 3-76.

9 William Shakespeare, The Rape of Lucrece, in The Poems, ed. John Roe (Cambridge: Cambridge Univ. Press, 1992), p. 161; 1. 352.

10 Samuel Richardson, Clarissa, or The History of a Young Lady, ed. Angus Ross (New York: Viking, 1985), p. 879 . 
her. Although he acknowledges that "There's no triumph over the will in force!" (p. 879; emphasis in original), the only way he can defeat her will is by obligating her to marry him - which necessitates the assault.

Clarissa's stronger "resolution" can make Lovelace's will buckle, and although it cannot stop him from abducting or violating her, it ultimately denies him both possession of her and his own peace of mind. She tells Lovelace that she is "resolved" not to leave her parents' house with him (p. 374), but he tricks her into fleeing. After the assault she still refuses him, and one night when he deceives her into leaving the sanctuary of her room, she threatens to kill herself if he does not relent, "grasping resolutely" the handle of a penknife that she holds to her chest (p. 950). After Lovelace backs down she tells him: "The resolution you have seen, I trust God will give me again upon the same occasion" (p. 951). ${ }^{11}$

Novelists prior to Richardson had established that threatened women must resort to strategies like Clarissa's because they cannot rely on their physical abilities. For example, when the heroine of Eliza Haywood's Idalia, or the Unfortunate Mistress (1723) is threatened by the villain Ferdinand, she tells him that she will stab him, but she turns the knife toward herself after she realizes how easily he can seize it from her. ${ }^{12}$ (Yet Haywood's

11. On Richardson's continual allusions to the Lucretia story, see Ian Donaldson, The Rapes of Lucretia: A Myth and its Transformations (Oxford: Clarendon Press, 1982), pp. $57-82$.

12 See Margaret Anne Doody, A Natural Passion: A Study of the Novels of Samuel Richardson (Oxford: Clarendon Press, 1974) pp. 146-47. The question of which direction the knife ought to point was still being explored during Scott's and Cooper's lifetimes. In the climactic scene of Charles Brockden Brown's Ormond; or the Secret Witness (1799), Constantia tells the villain Ormond: "my unalterable resolution is to die uninjured," and so she will stab herself to prevent his assault. What ensues subverts convention but also defies probability. Although Constantia has determined that Ormond will probably fend off any attack she makes, she soon disregards her rational evaluation of her plight, stabbing him to death in "a momentary frenzy" with a knife-thrust that is "desperate and at random" (Charles Brockden Brown, Ormond; or the Secret Witness, ed. Ernest Marchand [New York: Hafner, 1962], pp. 234, 240). Constantia's success is hardly more probable than Bois-Guilbert's collapse in Ivanhoe: it relies too heavily on the chance ("at random") that Ormond will not avoid her thrust. Brown's conclusion is such blatant wishful thinking that it underscores the unreliability of any defense except suicide, and Ormond thus exemplifies the means by which chivalry is provided with a need to fill. 
novel shows that not all men will falter as Lovelace does: Ferdinand tricks Idalia into feeling safe and eventually proceeds to assault her.)

In Clarissa Richardson makes clear that failures in chivalry bear part of the blame for Lovelace's succeeding as much as he did. After Clarissa's death Lovelace responds to Belford's reproaches by accusing his friend of affecting knighthood without "the true spirit of chivalry" (p. 1,44o): Lovelace had told Belford what he was planning, and he responded by doing nothing. In place of Shakespeare's political allegory Richardson provides class allegory, in which the corrupt aristocrat is thwarted and finally killed in a duel. For Richardson the age of chivalry is not gone; chivalry merely has moved a rung lower on the class ladder. Class allegory persists in Scott, and is joined to national allegory, but with him the vindication is far more hollow.

From Lucrece to Clarissa to Ivanhoe, the villain's resolution keeps weakening, and, as a consequence, the woman's resolution becomes more effective in preventing her sexual violation. Since beginning with Scott the assault is prevented, the question of whether the victim will kill herself or waste away becomes moot: if the heroine dies, it will not be because of the violation but because she is executed or murdered. Death thus is no longer a consequence of sexual assault but an alternative to itthe villain offers her a choice that is, plainly, no choice at all. And her superior resolution, although it may evade the first of the threats, cannot evade both of them.

Scott follows Richardson's course when his heroine's resolution paralyzes the villain, yet he is writing in a different world and feels different imperatives. Scott's demonstrable investment in chivalry was one factor that forced him to amend the motifs provided by eighteenth-century narratives of threatened women, including not only Clarissa but also Gothic novels and Indian-captivity narratives. In his 1817 Encyclopeedia Britannica article on chivalry Scott wrote that "from the wild and overstrained courtesies of chivalry has been derived our present system of manners," and within this system a gentleman knows that "the rights of the weaker sex demand protection from every one who would hold a good character in society" (Scott, "Chivalry," III, 126). The core of chivalry that Scott celebrates 
conforms to the working definition of chivalry that I gave at the outset. Scott's article demonstrates consistently that he would resort to tortuous arguments in order to vindicate chivalry's invaluable essence, usually trying to isolate it by filtering away chivalry's corrupt or "wild and overstrained" institutions. ${ }^{13}$

Although Ivanhoe deromanticizes the Middle Ages and satirizes abuses typical of the era (such as those stemming from "superstition"), it ultimately tries to insulate the chivalrous spirit from the implications of this critique. As Marilyn Butler observes, one unexpected feature of Ivanhoe is "the amount of human suffering Scott depicts within a medieval and legitimist society. His representation could be seen as almost cynical-a world bonded neither by religious ardour nor by chivalric dedication, but by guile and brute force." ${ }^{14}$ Ivanhoe's heroic effort to save Rebecca, I would add, represents an attempt to rescue the novel from its drift into this cynicism. What propels the narrative, particularly as it approaches its conclusion, is a desire to recuperate chivalry, even though contrary impulses prevent that recuperation. Scott would prefer to forget what he knows about chivalry's unreliability (as his encyclopedia article reveals), yet he cannot quite do so. The climactic judicial combat scene clearly embodies frustration at being unable to devise a resolution that is both reassuring and believable. BoisGuilbert's death is, too clearly, neither.

The moment of Ivanhoe's composition is a key to its problematic ending. Showing that British men of the higher classes were foremost in chivalry, and in the chivalrous protection of women, never had more to offer Scott than it did late in 1819 , when he was finishing the novel. The catalyst was "Peterloo," the Manchester yeomanry's bloody attack on a radical mass meeting, which occurred on 16 August 1819. Scott ran to the defense of the Manchester authorities, and over the follow-

${ }^{13}$ See Gary R. Dyer, "Ivanhoe, Chivalry, and the Murder of Mary Ashford," Criticism, 39 (1997), 394-96, on the contradictions and tensions within Scott's chivalry article. As Joseph Phillimore's and Charles Mills's observations evince (note 3, above), Scott was far from unique among contemporary writers when he distinguished chivalry's forms from its spirit and celebrated this spirit's endurance.

${ }_{14}$ Romantics, Rebels and Reactionaries: English Literature and Its Background, r7601830 (New York: Oxford Univ. Press, 1981), p. 15 o. 
ing months he became obsessively fearful of real and imaginary radical uprisings. This, Graham McMaster has argued, was the one occasion when Scott "lost his political nerve." 15 The radicals whom Scott vilified were claiming the chivalrous high ground insofar as they depicted the British establishment as violators of women: a poem in the Theological and Political Comet composed by "R. S." (Robert Shorter) surveyed the "plain" where "Wives, mothers, children" lay "in one promiscuous heap," and it sarcastically assured the yeomen: "You all shall live in deathless fame, / For chivalry you there did show." 16 Scott wrote the last of Ivanhoe's three volumes, which includes the trial by combat, between August and November 1819. ${ }^{17}$

In the trial by combat the Saxon hero, Wilfrid of Ivanhoe, fights against the Norman Templar Bois-Guilbert in defense of the Jewish heroine, Rebecca, who has been accused of bewitching Bois-Guilbert. The Templar falls dead, killed not by Ivanhoe but by "the violence of his own contending passions." The only two passions the reader has seen in Bois-Guilbert are his desire to possess Rebecca and his need to defeat her champion in order to ensure that he will succeed to the leadership of the Templars. At this point in Scott's career, questions of justice are inextricable from questions of gender, and in Ivanhoe he tries to answer all of these questions by having Bois-Guilbert's irresolution kill him. This is a deus ex machina, yet with no deity in sight: although Ivanhoe and the Templar Grand Master, Lucas Beaumanoir, attribute Bois-Guilbert's death to "the judgment

15 Scott and Society (Cambridge: Cambridge Univ. Press, 1981), p. 90.

${ }^{16}$ R[obert] S[horter], "The Bloody Field of Peterloo! A New Song," Theological and Political Comet (1819), 85-86; rpt. in Poetry and Reform: Periodical Verses from the English Democratic Press, ed. Michael Scrivener (Detroit: Wayne State Univ. Press, 1992), pp. 218-19, 1l. 33-34, 9-10. As Linda Colley has observed, "every political cartoon published attacking this episode gave prominence to armed men, pursuing, or riding over, or cutting down women" (Britons: Forging the Nation, $1707-1837$ [New Haven: Yale Univ. Press, 1992], p. 264). See Dyer, "Ivanhoe," pp. 396-97, on the relation between Peterloo and Ivanhoe.

17 On 19 August, three days after Peterloo, he had finished writing the second volume of Ivanhoe (see Scott, letter to James Ballantyne, 19 August 1819 , in The Letters of Sir Walter Scott, ed. H.J.C. Grierson, et al., 12 vols. [London: Constable and Co., 193237 ], V, 465). By 8 November (to John Ballantyne) Ivanhoe was "almost all finishd and in the transcribers hands" (Letters, VI, 6); by to November (to Daniel Terry) it was "completed" (Letters, VI, 11 ). 
of God," their explanations have been preemptively rejected by the narrator, who points instead to Bois-Guilbert's "contending passions." 18 Ivanhoe wins only because Bois-Guilbert abruptly falls dead; this odd occurrence serves to resolve on the fictive level the contradictions involved in asking men to monopolize power but not to misuse it. Because Scott is uncertain that chivalry will serve justice (an uncertainty that contemporary events could only aggravate), he must find another route, so he relies on the villain halting. At the same time, the fact that this occurrence is so unusual reveals an antithetical purpose at work within Scott's narrative: a desire to hold up these contradictions for the reader to see. The messy result seems less to reflect irony than confusion and conflict: Bois-Guilbert is not the only one torn by contrary drives. ${ }^{19}$

For Scott, as later for Cooper, there are two paths to a consoling narrative resolution that will reflect well on chivalric male authority: the hero saving the woman on his own, or the villain's resolution failing. Although each author presumably would prefer the first option, his hero is finally inadequate to the task; instead, what saves the woman is the villain's inability to reconcile or choose between his conflicting drives. When the villain's failure of resolution spares the woman, the text permits a hasty reader to assume that it is some remnant of virtue that has halted the villain. Against what Scott's chivalry article and other sources show to be his predominant wishes, Ivanhoe undercuts the ideology of chivalry by showing how the chivalric protection of women is not disinterested but rather is dependent on sexual desire. One reason that chivalry is precarious is that the sublimation of sexual desire is never complete or irreversible: instead of being nullified, it is merely deferred. In The Last of the Mohicans Cooper reiterates this insight, but he also points out

18 There is a long tradition of normalizing Bois-Guilbert's death, which began with the London Magazine reviewer who wrote that "the Templar falls under the arm of heaven, rather than under that of his adversary" (rev. of Ivanhoe, The London Magazine, 1 [1820], 84). See also Dyer, "Ivanhoe," pp. 405-6, n. 21.

19 This paragraph summarizes the argument I make in my earlier essay "Ivanhoe." That essay relates Scott's combat scene to the famous 1817-18 case Ashford $v$. Thornton, a case that dramatized these contradictions within chivalry. Abraham Thornton escaped punishment for raping and murdering Mary Ashford when he claimed his right to judicial combat, a right that, to the nation's shock, was still in effect. 
the corollary: chivalry is ineffective outside of an economy governed by desire. Cooper's novel revises Scott's insofar as it demonstrates less the unlikelihood that irresolution will cripple the villain than the unlikelihood that his impairment will save the woman. The "rescue" that is decisive at the end of Ivanhoe is only momentary in The Last of the Mohicans.

Scott does not identify the passions that Bois-Guilbert cannot resolve, and this vagueness about the villain's motives discredits any claims the novel makes on behalf of chivalric ideology. There is no proof that either of Bois-Guilbert's contending drives is virtuous, as neither one is demonstrably a remnant of a chivalrous, disinterested commitment to defending women (according to Burke, chivalrous men venerate women "without any consideration whatsoever of enjoying them"). More important, Scott, by not identifying the villain's contending forces, makes clear that the reader has no means to decide whether the guiding motive of a male character, hero or villain, is disinterested virtue or simply his need to preserve the life of the woman in order to possess her sexually.

The confusion between the two motives implies their mutual dependence, which can almost be unity. Although, when taken in isolation, an individual chivalrous act may be disinterested (for example, Ivanhoe gains nothing directly if he saves Rebecca), chivalry as an ideology is intrinsically patriarchal: based on preserving in order to possess, it serves men's interests and validates male domination. While the villain's irresolution is not necessarily a result of chivalric impulses, we must also bear in mind that chivalry is not necessarily the impartial regard for right that it professes to be. Burke acknowledges that in order to become disinterested, men must first feel passion and then sublimate it: a chivalrous man venerates a woman after he recognizes her "Beauty." While as readers we cannot be certain that whatever remnants of chivalry persist in the villain are virtuous, we cannot be sure about the hero's chivalry either. Scott's novel reveals chivalry to be an ideology that authorizes giving men nearly total power while expecting that they will use that power contrary to their own interests. Yet at times (such as in Scott's judicial combat scene) that expectation seems to be degenerating into mere hope. 
The final combat scene is not the first time in Ivanhoe that Bois-Guilbert's resolution falters, and the most memorable instance in fact builds on Richardson's penknife scene. About midway through the novel Bois-Guilbert and his Norman cohorts kidnap Rebecca, and she is taken to a tower. BoisGuilbert goes there with the intention of raping her, but he is thwarted when she rushes to the parapet and threatens to jump to her death. The Templar now encounters "her high and firm resolve," her "indomitable pride and resolution" (pp. 200, 203), and faced with this display, his "resolution which had never yielded to pity or distress, gave way to his admiration of her fortitude" (p. 199). The verbal repetition is key: her "resolution" robs him of his own.

No Scott character wavers more than Bois-Guilbert, not even Waverley. When Rebecca is being held as a sorceress, BoisGuilbert tells the preceptor of Templestowe, Albert Malvoisin: "I will leave her to her fate, unless"-and here his friend interrupts: "Qualify not thy wise and necessary resolution" (p. 316). Later, Bois-Guilbert tells Rebecca that he curses Malvoisin because Malvoisin "withheld [him] from the resolution [he] had formed," his resolution to refuse the combat (p. 341). When she again resists him, however, Bois-Guilbert tells her: "I have assailed thy resolution in vain, and mine own is fixed as the adamantine decrees of fate" (p. 345). So Bois-Guilbert will fight on behalf of the accusation against her, as Beaumanoir commanded. But a moment later he confides to Malvoisin that Rebecca has "well nigh unmanned" him, so that he is "half resolved" to say no (p. 346). When Malvoisin points out how his plan is impractical, Bois-Guilbert replies, "I will resume my resolution" (p. 347); yet the preceptor still deems it necessary to follow him to "confirm him in his resolution" (p. 347). Malvoisin's concern is justified: before the combat, Bois-Guilbert's face bears "a strange and mingled expression of passion, in which pride seemed to contend with irresolution" (p. 385 )he cannot resolve even a conflict over his own irresolution. After Ivanhoe arrives, Bois-Guilbert turns toward Rebecca "irresolutely" (p. 390). When Beaumanoir asks whether Rebecca is "resolute in her denial," Bois-Guilbert responds that "she is indeed resolute" (p. 389; emphasis Scott's-or, more to the point, 
Bois-Guilbert's). The reader can be excused for thinking that Bois-Guilbert is reflecting on how Rebecca's superiority in this characteristic has determined the course of their struggles.

Scott focuses on the word "resolution," whereas his predecessors Shakespeare and Richardson give equal stress to "will." Unlike "will," "resolution" acknowledges the persistence of inner conflict - the power of unconscious desires and the fallibility of conscious control. Often "resolution" dissolves quickly, but given the tensions within the human psyche, it may be the most that a person can achieve. Almost the only "will" that characters in Ivanhoe invoke is God's, and in the combat scene God is significantly absent. In Scott, as in Richardson, inner conflict is more typical of evil characters than good ones, and evil men find it difficult to stay resolute. ${ }^{20}$ Still, these men's difficulties cannot hearten the reader, because before they waver they are resolute enough to do considerable harm.

Although Bois-Guilbert is immune to the pity that temporarily disables Lovelace, he suffers from similar helplessness when the woman he pursues threatens suicide. The tactic that rescues Clarissa from further violation, however, backfires on Rebecca, whose threat succeeds in changing Bois-Guilbert's attitude. Before she goes to the parapet he tells her: "nor will I . . abstain from taking by violence what thou refusest to entreaty or necessity" (p. 198); afterward he tells her: "Mine thou must be!"-but also, "it must be with thine own consent, and on thine own terms" (p. 201). The ensuing events show, nevertheless, that his waiting for her consent concedes nothing, because he will not allow her to refuse. He even declines to ask her to forgive his attempt at rape, telling her that the threat "was necessary to the display of [her] character" (p. 202). Her strength earns Bois-Guilbert's admiration, yet it thereby attracts him all the more; later, when she faces death at the stake, he refuses to rescue her unless she agrees to become his concubine.

In 1833 Harriet Martineau argued that society degrades Rebecca "as a woman, no less than as a Jewess," and that her suf-

${ }^{20}$ Jeffrey N. Cox points out that in Gothic fiction "having an interesting consciousness, being possessed by unconscious desires, is a mark of villainy" (introduction to Seven Gothic Dramas, $x 789-1825$, ed. Cox [Athens: Ohio Univ. Press, 1992] , pp. 28-29). 
ferings make her women's "representative." 21 The oppression of women becomes more central to Ivanhoe as the story proceeds, because increasingly it focuses on Bois-Guilbert's libidinous pursuit of Rebecca. ${ }^{22}$ Moreover, she represents women by being resolute as well as by being persecuted. When The Ladies' Monthly Museum declared that Rebecca displays "that passive fortitude which is woman's proudest boast," 23 a fundamental truth lay beneath the reviewer's complacency: Rebecca's resolution surpasses Bois-Guilbert's because she has more often been obliged to cultivate it. Like Shakespeare and Richardson, Scott simultaneously demythologizes resolution (when men's determination leads to crime) and feminizes it (when the women's fortitude can give them a victory); resolution becomes less a sign of male strength and more a sign of female forbearance. The resolution is passive, however, and the victory is partial. Women need this passive fortitude more than men do, yet, as Scott makes clear, it soon becomes fetishized, and therefore it backfires. A woman's resolution becomes something that prevents or delays gratification, and thereby only intensifies a man's need for that gratification.

Vindicating chivalry matters to Scott, even in a novel that so often deromanticizes the Middle Ages, and that is why he goes to such lengths to award victory, even a tarnished victory, to Ivanhoe. In order to do so, Scott disregards plot options provided to him by the tradition of resolute heroines and irresolute villains as it had evolved after Richardson. Thomas Holcroft's novel Anna St. Ives (1792), for example, evokes this tradition only to depart from it in accordance with the author's radical political program. ${ }^{24}$ When Coke Clifton relents in his at-

21 "The Achievements of the Genius of Scott," Tait's Edinburgh Magazine, 2 (1832$33), 45^{6 .}$

${ }^{22}$ The early chapters of Ivanhoe suggest that the novel's primary theme will be the conflict between "the two rival nations" of Saxons and Normans (p. 41), and the book soon makes clear how commonly women are used as vehicles for this conflict. Each side is eager to accuse the other of violence against women, as we see when the Normans De Bracy and Bois-Guilbert disguise themselves as Saxons to abduct the party that includes Rowena and Rebecca.

${ }^{23}$ Rev. of Ivanhoe, The Ladies' Monthly Museum, ser. 3, 1 ( (1820), 99.

${ }^{24}$ See Thomas Holcroft, Anna St. Ives, ed. Peter Faulkner (London: Oxford Univ. Press, 1970). Scott had a 1792 edition of Anna St. Ives in his library at Abbotsford (see Catalogue of the Library at Abbotsford [Edinburgh: Bannatyne Club, 1838], p. 332). Brown's Ormond and Susanna Rowson's Charlotte: A Tale of Truth (1791) are two other 
tempt to assault Anna, he complains to his correspondent Fairfax that he finds himself "torn by contending passions" (p. 424), yet Clifton differs from the similarly torn Lovelace and BoisGuilbert (and Cooper's Magua) in one crucial way: the force within that stops him is clearly moral. Instead of threatening to kill herself, Anna appeals to her tormentor's submerged respect for justice; Scott's Rebecca does the same, but Anna alone is successful. Not only do Holcroft's virtuous characters deem suicide and revenge unjustifiable, but they also can prevent them by means of rational argument. Holcroft's implicit critique of chivalry stays general, and this critique interests him less than putting forward an alternative that is grounded in reason. Moreover, he does not identify such use of reason with a particular class, gender, or nation. Holcroft can break free from convention in these ways because his prior investment in the ideology of chivalry is negligible, and it is telling that the path that Holcroft chooses is one that Scott, writing a few decades later, does not acknowledge.

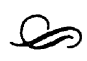

Whereas Ivanhoe shows that the heroine's resolution is not enough to save her (that requires the author's contrivance), The Last of the Mohicans shows that not all evil men will be as irresolute as Bois-Guilbert. Cooper thought that Ivanhoe, though "very unequal," "stood quite at the head of the particular sort of romances to which it belonged," and he used Scott's novel as a model in structuring his first work of fiction, Precaution (1820). ${ }^{25}$ In The Last of the Mohicans Cooper rewrites

novels published in Scott's lifetime that use the motif of resolution and irresolution. In Rowson's novel, commonly known as Charlotte Temple, Montraville pursues Charlotte in Lovelacean fashion, but in this work it is the man's suicide threat that weakens the woman's "resolution," and it is she who (as Montraville later points out) finds herself "torn by contending passions" (Susanna Haswell Rowson, Charlotte Temple, ed. Cathy N. Davidson [New York: Oxford Univ. Press, 1986 ], pp. 47, 93). This very uncertainty is what Montraville takes as a license to decide for Charlotte, and to spirit her off.

${ }^{25}$ James Fenimore Cooper, Gleanings in Europe: France, ed. Thomas Philbrick and Constance Ayers Denne (Albany: State Univ. of New York Press, 1983), p. 250; and see James Fenimore Cooper, letter to Andrew Thompson Goodrich, 31 May 1820, in The Letters and Journals of James Fenimore Cooper, ed. James Franklin Beard, 6 vols. (Cambridge, Mass.: Belknap Press of Harvard Univ. Press, 196o-68), I, 4². Scott's influence on Cooper has never been in doubt, but critics tend to scrutinize broad continuities 
key moments from Ivanhoe so as to emphasize chivalry's inadequacy, for indeed the specific failing of chivalry that condemns his heroine-its ineffectiveness in protecting white women from red men-implicitly indicts it as a whole.

At the climax of The Last of the Mohicans Cora refuses to continue to flee with her captor, the Huron Magua. She halts on a mountain ledge and kneels to God, simply saying to Magua: "Kill me if thou wilt" (p. 336). Two of his compatriots are about to oblige, but Magua throws away their tomahawks; he then finds that his resolution fails, just as Bois-Guilbert's did. Magua looks at Cora, his face betraying his "conflicting passions," and he tells her that he will kill her if she refuses to become his squaw. He repeats himself when she does not respond, yet then he discovers that he cannot carry out his threat. Twice he lifts his knife without striking a blow: "he raised his arm on high, but dropped it again, with a bewildered air, like one who doubted" (p. 337). Merely by asking Cora to choose, Magua divulges his reluctance to kill her. After all, twice earlier in the book she told him that she would choose death over such "dishonor" (pp. 108, 178). But the pair of unnamed Indians who accompany him feel no such conflict, and, when Magua is distracted by Uncas's attack, one of them stabs Cora to death. Magua pursues the guilty Huron, only to kill Uncas instead; moments later, Hawk-eye shoots Magua dead.

Cooper does not say why Magua falters when he threatens Cora on the precipice, but he has never encouraged us to credit him with much respect for human life. The drives that impel Magua are termed "passions," which suggests that if one of them is sexual, then the other is violent. Fulfilling either desire will satisfy his need for revenge on Cora's father, Colonel Munro, but Magua's hesitation suggests that he wants to possess her alive. His dilemma, then, seems clear: he wants her to be

rather than local ones like those at issue here, and practically no critic has related the roles that gender plays in each man's fiction. The best analyses are Donald Davie, The Heyday of Sir Walter Scott (New York: Barnes and Noble, 1961); George Dekker, James Fenimore Cooper: The Novelist (London: Routledge and Kegan Paul, 1967); and Dekker, The American Historical Romance (Cambridge: Cambridge Univ. Press, 1987). Other novelists in the 1820 besides Cooper adapted Ivanhoe to the race and gender politics of the American frontier, the most compelling instances being two historical romances of Puritan New England, James McHenry's The Spectre of the Forest (1823) and Catharine Maria Sedgwick's Hope Leslie (1827). 
his squaw, and he can effect his will only by threatening her life; yet following through on the threat would deny him his goal.

As in Ivanhoe, the villain's (unspecified) contending drives subvert his designs, but in Cooper's novel it has the opposite outcome. In effect Cooper combines what in Scott are two separate scenes: the judicial combat and Bois-Guilbert's unsuccessful attempt on Rebecca in the tower. Cora's halting on the ledge reminds any reader who is familiar with this literary tradition of Rebecca's rushing to the castle parapet, as well as Clarissa's grasping her penknife. Just as Rebecca would prefer death to life with Bois-Guilbert, so Cora consigns herself to whatever is God's will. ${ }^{26}$ As Magua hesitates, a reader who remembers Scott's novel might expect that he will shortly drop dead; yet Cooper rewrites Scott, so that the threat to the woman's life is fulfilled. Moreover, Cooper's ending is oddly anticlimactic: the heroine is murdered by someone who has no history in the novel-by a man who is never even named, a man with no identity other than his tribe. The implication seems to be that his ethnicity, in concert with his gender, can account for his actions.

Nina Baym has observed that in The Last of the Mohicans a white man "needs a woman to fight for and about." 27 After taking into account Cooper's debts to the Indian-captivity tradition, one would predict that men protecting women must be a central theme in the novel. British writers in the Regency period were following a well-worn path when they argued that their social class or their nation was most chivalrous; Americans likewise had a long tradition of fighting over who was best at protecting women, which generally meant protecting them from Indians. During the War of Independence, Americans justified their cause by condemning the British for unchivalrously taking Indians as allies: one of the examples of George III's tyranny

${ }^{26}$ Cora's appeal to God only serves to make conspicuous how the ensuing events lack signs of God's handiwork. Such signs are no more evident here than in Ivanhoe, in which Rebecca more than once futilely resigns herself to God's justice. In The Last of the Mohicans not even the pious psalm-singer David believes in supernatural agency (see p. 268).

27 "Putting Women in Their Place: The Last of the Mohicans and Other Indian Stories," in her Feminism and American Literary History: Essays (New Brunswick, N.J.: Rutgers Univ. Press, 1992), p. 26. 
that Thomas Jefferson listed in the Declaration of Independence was his efforts "to bring on the inhabitants of our frontiers the merciless Indian savages, whose known rule of warfare is an undistinguished destruction of all ages, sexes, \& conditions."28 The failure of Indian warriors to "distinguish" women from men was key. One crucial event in this mythology was the death of Jane McCrea: in 1777 she was murdered by Indians, in the region where The Last of the Mohicans is set, and after her killers were pardoned by their British allies her death became a rallying cry for the rebel cause. ${ }^{29}$ McCrea's murder retained its nationalist connotations into the nineteenth century: in John Vanderlyn's often-reproduced painting The Death ofJane McCrea (1804), for example, the two Indians wear British red, while McCrea, untrue to her actual loyalist allegiances, wears colonial blue.

A reading of The Last of the Mohicans suggests, as John P. McWilliams, Jr., points out, that "the protective reverence that some white men and 'white' Indians pay to white women may be Cooper's only sure means of maintaining the moral superiority of his own 'civilized' and conquering race." 30 The reverence is certain, but the protection is not: whereas in Ivanhoe chivalrous white men are adequate for every task except saving Rebecca, in The Last of the Mohicans they seem to fail continually. Major Duncan Heyward and the French general Montcalm are the two men whom Cooper links most often with knighthood and with the term "chivalry," yet Heyward's chivalry is ineffective and Montcalm's is superficial, which seems to point out chivalry's limitations as a guiding principle. Cooper twice notes Montcalm's “chivalrous courage” (pp. 153, 180), yet in the second instance he is acknowledging the general's complic-

28 "A Declaration by the Representatives of the United States of America, in General Congress Established," in Thomas Jefferson: Writings, ed. Merrill D. Peterson (New York: Library of America, 1984), pp. 21-22.

${ }^{29}$ See Mercy Otis Warren, History of the Rise, Progress and Termination of the American Revolution, Interspersed with Biographical, Political and Moral Observations, 3 vols. (Boston: E. Larkin, 1805), I, 25-27; Jay Fliegelman, Prodigals and Pilgrims: The American Revolution against Patriarchal Authority, I750-I80o (Cambridge: Cambridge Univ. Press, 1982), pp. 137-43; and June Namias, White Captives: Gender and Ethnicity on the American Frontier (Chapel Hill: Univ. of North Carolina Press, 1993), pp. 117-44.

30 The American Epic: Transforming a Genre, 1770-1860 (Cambridge: Cambridge Univ. Press, 1989), p. 141. 
ity in the Huron massacre of between five hundred and fifteen hundred women and children at Fort William Henry. ${ }^{31}$

There are men in The Last of the Mohicans whose chivalry is genuine, but it is nonetheless futile. Munro contrasts Montcalm's dubious claims to nobility with the Scottish Order of the Thistle, which he deems "the veritable 'nemo me impune lacessit' of chivalry!" (p. 157), voicing Scottish nationalism that would appeal to the author of Ivanhoe. But even though Munro and the Virginian Heyward observe the rules of chivalry, they have little success defending those who are under their protection. In Jefferson's account the British encourage Indian atrocities; in Cooper's the French do, yet they are taking advantage of British incompetence and cowardice. (Scott's chivalrous heroes often are ineffective, but their failures never have so great a cost.) After the massacre Munro is a pathetically listless, ruined man, worse than useless in rescuing his daughters, and although Heyward best fits the slot in the novel reserved for the protagonist, his undeniable effort and bravery often appear irrelevant, inadequate to protect the Munro sisters.

An early scene encapsulates how Heyward envisions his assignment to escort Cora and her half-sister Alice to Fort William Henry as the duty of a medieval knight. Heyward is "resolutely determined, in his own mind, not to close an eye until he had delivered his precious charge into the arms of Munro himself." But exhaustion overtakes him, and he sinks "into a deep sleep, dreaming that he was a knight of ancient chivalry, holding his midnight vigils before the tent of a re-captured princess, whose favour he did not despair of gaining, by such a proof of devotion and watchfulness" (p. 129). Heyward's notion of chivalry, no doubt derived from redactions of medieval romance, here pulls him into impractical fantasy, which too easily substitutes for action. Instead of keeping watch over Alice

31 See Robert Lawson-Peebles, "The Lesson of the Massacre at Fort William Henry," in New Essays on "The Last of the Mohicans," ed. H. Daniel Peck (Cambridge: Cambridge Univ. Press, 1992), pp. 120-21, in regard to Montcalm's failures as failures in chivalry. On the massacre at Fort William Henry, see also Ian K. Steele, "Cooper and Clio: The Sources for 'A Narrative of 1757," Canadian Review of American Studies, 20, no. 3 (1989), 1 2 1-35; and Steele, Betrayals: Fort William Henry and the "Massacre" (New York: Oxford Univ. Press, 1990). 
and Cora, he merely dreams that he is doing so-and this passage draws attention to the substitution, because the novel seldom depicts characters' thoughts directly. Envisioning himself as "a knight of ancient chivalry" does not make Heyward effective in protecting the Munro sisters any more than Montcalm's "chivalrous courage" moves him to prevent his Huron allies from slaughtering women and children.

The fact that Heyward only dreams about keeping watch is merely the most superficial defect in his knighthood. In order for chivalry to be dependable it ought to be disinterested, yet insofar as Heyward's dream includes only one princess, it suggests that his desire for Alice overshadows his promise to Munro to safeguard both of his daughters. For Heyward watchfulness is not an end in itself (or something that God alone will reward) but something that can win Alice's favor. When Cooper writes that Montcalm's failings reveal "how easy it is for generous sentiments, high courtesy, and chivalrous courage, to lose their influence beneath the chilling blight of selfishness" (p. 180), he is inviting his readers to search for selfishness beneath all of the generous and chivalrous sentiments and actions in the novel, and we discover it even in the novel's heroes.

At the same time, what draws Heyward to this particular woman are the opportunities she provides for his knightly devotion: he has chosen the sister who seems to need male protection more. As Baym writes, "although Alice's extreme passivity constantly endangers her and her companions, it turns out that by preserving this woman a high civilization signifies itself" (p. 26). Heyward feels "tenderness" for Alice, but only "admiration" for Cora (Mohicans, p. 150); this distinction is important because, as Baym observes, the word "admiration" "implies that the person so thought of is higher than the person who does the thinking, hence in no need of help from that person" (Baym, p. 28). Heyward's choice makes even more apparent the fatal gap in the economy of chivalry. The fact that Alice is not the sister who ends up more imperiled shows how the chivalric system fails when the woman whom a "knight" guards, and often desires, is not the woman whom his unchivalrous opponent wants: the only woman saved in The Last of the Mohicans is the one who interests the hero but never interests the villain. 
But then the cause of this error may be race, either Magua's or Cora's, because in the world of Cooper's novel a white man's assumption that the weaker woman will be desired (and therefore threatened) would be reasonable only if his opponent were not an Indian. Another factor may be that the women whom civilization seeks to preserve must be white. Not the least of Cooper's borrowings from Scott is the convention of juxtaposing "dark" heroines like the Jewish Rebecca with "light" ones like the Saxon Rowena: Cora's mother was partially of African descent, and this background alone would seem to make her a less-obvious object for chivalrous protection than the goldenhaired Alice. ${ }^{32}$

Munro's and Heyward's duties tend to fall on Hawk-eye and his Mohican companions Chingachgook and Uncas, three men whose chivalry is hard to gauge. The only time that the word is applied to them is when the narrator refers to Chingachgook's "chivalrous scalping tuft" (p. 29), and in this case Cooper may intend to be ironic. The three men appear unchivalrous when they leave Heyward, David, and the two women at Glen's Falls ("The white man thinks none but cowards desert their women" [p. 91], Heyward informs Magua), but Cora had urged them to flee (p. 78 ); it is more telling that they, not Heyward, end up rescuing the women from the Indians. Chingachgook, who faithfully stands guard while Heyward dreams about being a knight, has little or nothing to gain from his dedication. We might infer that the best protector for the women would be a man so disinterested, but during the final pursuit of the Indians who hold Cora, we see that such a man may not be motivated enough. Uncas goes first, followed by Heyward and then Hawk-eye, and the scout's greatest impediment may be that he is "not sustained by so deep an interest in the captive as his companions" (p. 336). Hawk-eye, in fact, is not attracted to

32 The light and dark heroines of fictional romance are a familiar topic in criticism. On Scott's heroines the standard work remains Alexander Welsh, The Hero of the Waverley Novels, with New Essays on Scott (Princeton: Princeton Univ. Press, 1992), pp. 48-55. On The Last of the Mohicans, see Leslie A. Fiedler, Love and Death in the American Novel (New York: Criterion Books, 196o), pp. 203-6; and Joel Porte, The Romance in America: Studies in Cooper, Poe, Hawthorne, Melville, and James (Middleton, Conn.: Wesleyan Univ. Press, 1969), pp. 20-22. But see also Baym, pp. 26-27. 
women in this or any of the first three Leatherstocking novels (for that, Cooper's readers had to wait until The Pathfinder, published in 1840). ${ }^{33}$ The sole task that the dispassionate scout performs in the climactic scene-shooting Magua - is carried out after Cora is dead. The chase serves to illuminate the relation between desiring and defending women: just as Heyward feels less for Cora than Uncas does, so Hawk-eye feels less than Heyward-while Chingachgook is nowhere to be seen.

Uncas's involvement, indeed, goes deepest. Early on he develops feelings for Cora, and those feelings make him reluctant to leave the women at Glen's Falls. Well before Heyward goes to sleep on duty, Alice indicates that this "fearless and generous looking" Indian might be a rival for the job of protecting her and her sister (p. 53). Unlike his father, Uncas represents, if not the noble savage, then the savage evolving toward nobility, and this evolution is reflected in his protectiveness toward the women (with an air of expertise, one reviewer, W. H. Gardiner, called this "chivalry" implausible) ${ }^{34}$ Yet even a man as motivated, skillful, and virtuous as Uncas can fail to save Cora, particularly with enemies who are as persistent as Magua and as savage as his Huron companions. Furthermore, the novel's homage to the prospect of Indian nobility is entirely retrospective: Uncas dies.

We know from Ivanhoe that when chivalrous men cannot protect women, the burden of their defense falls on the women's own will; since Heyward's resolute determination cannot even keep him awake, a lot is riding on Cora's resolution. Fortunately her resolve looks as strong as one could hope for, and Heyward even tells the French general that he would trust the defense of the fort to Cora, "were nothing but resolution necessary to repel so accomplished a soldier, as M. de Montcalm"

${ }^{33}$ Hawk-eye is curiously free from an indirect form of sexual transgression that Annette Kolodny has identified and analyzed: throughout The Last of the Mohicans the land is represented as a woman's body that men violate, and one key to the Leatherstocking novels is that Hawk-eye stands as the sole white person who "can enjoy the darkened forest recesses without threatening to become either destructive or intrusive" (The Lay of the Land: Metaphor as Experience and History in American Life and Letters [Chapel Hill: Univ. of North Carolina Press, 1975], p. 89; see also pp. 96-101).

${ }^{34}$ See [W. H. Gardiner], rev. of The Pioneers and The Last of the Mohicans, by James Fenimore Cooper, The North American Review, 23 (1826), 167-68. 
(p. 154). Here Heyward adopts the terminology of the seduction tale, except that the man whom Cora is deemed fit to repel is not an aristocratic rake but an aristocratic sponsor of indiscriminate murder. Another fact bodes well for Cora: Magua's resolution is uncertain at best, and Cooper makes clear that it can be undone by her fortitude. When they stand before the aged chief Tamenund, Cora gazes at Magua "with an eye so calm and firm, that his resolution wavered" (p. 3o3). After Hawk-eye offers to become Magua's prisoner in exchange for Cora, Cooper tells us that Magua "paused, and for an anxious moment, it might be said, he doubted." Magua then becomes resolute before Cora, exactly as he would wish: "casting his eyes on Cora, with an expression in which ferocity and admiration were strangely mingled, his purpose became fixed for ever" (p. $3^{1} 5$ ). Nevertheless, "for ever" lasts only until the moment later that day when he stands over her-again doubting, his purpose again wavering. Magua's will merely appeared to him to be unchangeable. Now his passions are not simply mingling but contending fiercely, and they stop him from acting. Although he could reconcile his "ferocity" with his "admiration," unspecified passions impede him.

But, as we know, someone else is there to kill Cora. Heyward says that she could defend the fort if "nothing but resolution" were necessary, yet, as Clarissa and Ivanhoe reveal, resolution is never good enough as a defense. It is ironic that the factor that permits Cora to be murdered is a trait that Hawkeye described earlier as an Indian form of restraint. Contemporary racist stereotypes come into play here, separating Cooper's Indians from Scott's Normans. Putting aside the question of how infrequently Indians actually violated female captives, we must recognize that charges of sexual abuse are rare in captivity narratives, or at least in the narratives published before Cooper's novel. Instead of being seen as virtuous, however, Indians' restraint was usually attributed to a disgraceful lack of manly libido - a lack for which they compensated with murder. In his classic History of America (1777) William Robertson wrote that Indian men feel for women neither "that tender attachment which takes place in civilized society" nor "that ardent desire 
conspicuous among rude nations," desire visible in "the negro" and "the most uncultivated Asiatics." 35 The naturalist Buffon blamed "the scattered life of savages" and "their estrangement from society" on their "hav[ing] been refused the most precious spark of Nature's fire," insofar as "they have no ardour for women." ${ }^{36}$ The captivity tradition, both fictional and nonfictional, implied that this deficiency freed other appetites: the Indians in Charles Brockden Brown's frontier Gothic Edgar Huntly (1799) want only to kill and scalp white women, nothing more.

Hawk-eye tells Heyward that the sole threat that Indians pose to women is murder: "I know your thoughts, and shame be it to our colour, that you have reason for them; but he who thinks that even a Mingo would ill treat a woman, unless it be to tomahawk her, knows nothing of Indian natur, or the laws of the woods" (p. 215). That Heyward's worries are so reasonable shames his race because white men do rape women. But the "natur" of Indians, according to Hawk-eye, would not impel them to the same crime, even if the "laws of the woods" did not interpose ${ }^{37}$ Although Cooper's narrative as a whole stresses the Hurons' zest for murdering women (and children), Hawk-eye

35 William Robertson, History of America, 3 vols. (Dublin: Price, et al., 1777), II, 46.

36 Georges Louis Leclerc, Comte de Buffon, Natural History, General and Particular, 8 vols. (London: W. Strahan and T. Cadell, 1781 ), V, 1 go.

37 When Hawk-eye points simultaneously to Indians' nature and to the "laws of the woods," the scout brings together two explanations for their sexual restraint that previously had been put forward as alternatives, with nature being the more ignominious. Buffon argued that Indian men had an innate deficiency, but Charles Thomson, in his observations appended to Jefferson's Notes on the State of Virginia (1787), responded that the "seeming frigidity" of Indians was "the effect of manners, and not a defect of nature" (Thomson, "Appendix No. 1," in Thomas Jefferson, Notes on the State of Virginia, ed. William Peden [1787; Chapel Hill: Univ. of North Carolina Press, 1955], p. 20o). Many people found defenses like Thomson's unpersuasive. When C. F. Volney in 1803 wrote that an Indian man's apparent "weakness of the sexual passion" is actually a result of "principle, and the danger of his situation," his translator Charles Brockden Brown felt compelled to object in a footnote that an Indian "is not deterred . . . from the excessive indulgence of other appetites, more immediately and glaringly destructive of his safety and health than this" (C. F. Volney, A View of the Soil and Climate of the United States of America, trans. C[harles] B[rockden] Brown [Philadelphia: J. Conrad, 1804], pp. $370,370-71 \mathrm{n})$. In any case, even though Hawk-eye cites nature and custom both, nature necessarily gets priority: when Indians' inborn disposition rules out sexual assault, the laws of the woods become superfluous. 
subordinates this propensity to the only moderation they display: an Indian, even one as vicious as a "Mingo," refuses not just to molest women but even to "ill treat" them. ${ }^{38}$

When the scout qualifies his commendation of the Indians ("unless it be to tomahawk her"), he shows that any resemblance between their moderation and chivalry is superficialthat this moderation is, in fact, the antithesis of chivalry. Chivalry has no power when sexual desire is absent, and such is apparently the case with Cora's murderer, who stabs her to death as if he cannot imagine a reason for which she might be spared; he can kill her because he does not want her. While the unspecified impulse within Magua that most clashes with his thirst for blood is surely not chivalry, it is, at least, the sexual desire that undergirds chivalry; Cora's killer evidently lacks both. Far from being a virtue, Indians' "natur" leads to the "undistinguished destruction of all ages, sexes, \& conditions" that Jefferson described. Men who are outside the economy of chivalry are immeasurably more dangerous to women's lives than men within it. ${ }^{39}$

38 Although the editors of the authoritative SUNY edition of the novel are right to note (Mohicans, p. 364) that Cooper may be thinking of the Moravian missionary John Heckewelder, who applauded the "moderation, humanity and delicacy" that Indians display toward female prisoners (see John Heckewelder, An Account of the History, Manners, and Customs, of the Indian Nations, Who Once Inhabited Pennsylvania and the Neighbouring States [Philadelphia: Abraham Small, 1818], p. 339), any such echo must be ironic, given how Hawk-eye limits his commendation. The novelist certainly had access to many other writings that interpreted Indian restraint less favorably than Heckewelder's did. Even the authority that Heckewelder cites, Jonathan Carver, goes on to admit that this moderation "is only inherent in those who have held some communication with the French missionaries" ( J[onathan] Carver, Travels through the Interior Parts of North America, in the Years 1766,1767 , and $1768,3^{d}$ ed. [London: C. Dilly, H. Payne, and J. Phillips, 1781], p. 343).

39 On the early-nineteenth-century stereotypes of Indian violence as infantile and presexual, see Michael Paul Rogin, Fathers and Children: Andrew Jackson and the Subjugation of the American Indian (New York: Alfred A. Knopf, 1975), pp. 118-25. On Cooper's knowledge of Indians and his depictions of them in his fiction, see Gary Ashwill, "Savagism and Its Discontents: James Fenimore Cooper and His Native American Contemporaries," American Transcendental Quarterly, n.s. 8 (1994), 21 1-27; Charles Franklin Beard, "Historical Introduction," in The Last of the Mohicans, pp. xv-xix; Randall C. Davis, "Fire-Water in the Frontier Romance: James Fenimore Cooper and "Indian Nature," Studies in American Fiction, 22 (1994), 215-31; David T. Haberly, "Women and Indians: The Last of the Mohicans and the Captivity Tradition," American Quarterly, 28 (1976), 431-43; Forrest G. Robinson, "Uncertain Borders: Race, Sex, and Civilization 
Indians feel only violent rage toward women who would attract white men, and it is evident at times that such women provoke their rage more than any other victims could. Early in The Last of the Mohicans Cooper has the Indians threaten Cora and Alice with "the most menacing gestures, against which neither the sex, nor the beauty of the sisters, was any protection" (p. 92). Their sex and beauty might be an invitation to spare them or an incitement to ravish them (though Cooper neglects the latter possibility as if it is too improbable to mention), yet these attributes either do not matter to the Indians or simply inflame their desire for blood. The second of these explanations is the more intriguing - that their violence is not entirely indiscriminate, as Jefferson would have it, but directed toward objects of other men's desire.

Magua, in contrast, does want to "ill treat" Cora in the sense that Heyward fears, and so he has a motive to spare her in the hope that she will change her mind. Gardiner protested in his 1826 review of the novel that Magua's "passions" were "anything but characteristic of the North American savage," and he doubted that an Indian would choose "so distant and so refined" a means of revenge on Munro "instead of taking the scalps of the ladies on the spot" (Gardiner, p. 170). By exempting Magua from the asexuality that contemporaries attributed to $\mathrm{Na}$ tive Americans, Cooper not only provides himself with someone more like a traditional Gothic lustful villain around whom to build his plot, but he also implies that Magua has been made this way by his contact with Europeans and by his conflict with Colonel Munro. (Also exempt, obviously, is Uncas, who in chivalrously aiding the women is "denying his habits, we had almost said his nature" [p. 1114$]$.) Magua's vacillation similarly separates him from his countrymen, since according to convention

in The Last of the Mohicans," Arizona Quarterly, 47, no. 1 (1991), 1-28; Richard Slotkin, The Fatal Environment: The Myth of the Frontier in the Age of Industrialization, I80o-I 890 (New York: Atheneum, 1985), pp. 81-106; and Slotkin, Regeneration through Violence: The Mythology of the American Frontier, I60o-I 860 (Middletown, Conn.: Wesleyan Univ. Press, 1973), pp. $4^{66-516}$. For an analysis of how women novelists in the 1820 put forward alternative views of Indian-white personal relations, see Baym, who explains that "The Last of the Mohicans rejects the woman-centered structure of [Lydia Maria Child's] Hobomok and reclaims the Indian story for white males" (p. 26). 
the Indian is the most resolute of beings-brave in suffering, persistent in revenge.

Magua's divorce from his origins is not complete, however. While Cora's murderer seems to lack Magua's lust, Magua shares his compatriot's bloodthirstiness, which can appear supernatural in its intensity. When Magua's two Indian companions are about to tomahawk Cora, they display "the impious joy that fiends are thought to take in mischief" (p. 336); Magua too is driven by this primitive rage, which turns out to have been one of his conflicting passions. After he "stayed the uplifted arms" of the two Hurons (p. 336), he "raised his arm on high" to substantiate his threat to Cora (p. 337). This repetition of images seems to equate Magua's impulse toward murder with the savagery driving the other Hurons, and the passage thus hints that Magua's threat is motivated not just by his strategy to force Cora's compliance but also by a passion for blood. After Cora's death this fury is Magua's only pleasure left, and, surprisingly, it suffices: after killing Uncas, Magua emits "a cry, so fierce, so wild, and yet so joyous" (p. 337), as if he has rediscovered the satisfaction that murder provides. Although the other Huron made the choice for him, Magua's disappointment is fleeting. The word "joyous," by making us think back a page to his accomplices' "impious joy," indicates that, in the end, Magua is a stereotypical Indian, with the same propensity for "undistinguished destruction." Indeed, we readers have already seen that if Cora is involved, then the only times that Magua can be resolute enough to act are when he is overcome by rage. For example, when Heyward and Alice endorse Cora's decision to refuse Magua, the Huron becomes so furious that he is about to kill them all (p. 110).

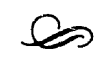

In The Last of the Mohicans chivalry is doubly compromised: not only is this ideology fatally dependent on the same desire to acquire women that motivates men who spurn it (which is the impasse in Scott), but it is also powerless when that desire is absent. Seen in historical context, Cooper's critique of chivalry has its own ideological function: in reject- 
ing chivalry he legitimates his own people's violence against the Indians, since nothing but physical force can defend women against the asexual or presexual destructive urges that supposedly drive Indian men. Everything depends, therefore, on the chance that the virtuous man will be strongest, and although that unattractive dependence on happenstance was the very dilemma that necessitated the ideology of chivalry in the first place, there is another way to avoid it: by invoking fate. And, indeed, one does not have to search far for contemporary versions of providence that could rise to the occasion-I am thinking not only of the notorious doctrine that attributed a "manifest destiny" to white Americans but also of its complement: many observers besides Cooper obscured the ongoing white aggression against Native Americans by representing the Indians' disappearance as more than inevitable, as a fait accompli.

The differences that I have delineated between Ivanhoe and The Last of the Mohicans may appear to result automatically from the different nations involved-from the fact that Cooper's unchivalrous villains are American Indians instead of Normans-but the matter is not so straightforward. In the late 1820 Cooper repeatedly centered his fiction on dangers to women, and he did not limit these dangers to the Indians who are so menacing in The Last of the Mohicans, The Prairie (1827), and The Wept of Wish-ton-Wish (1829): his female characters face comparably grave threats from white pirates in The Red Rover (1827), which is the Cooper novel that addresses most explicitly the question of which men and which institutions best assure women's safety. Cooper's focus on threatened women would prescribe border regions like the sea and the American forests as locales, just as choosing these locales would prescribe that women be threatened.

The contradictions within chivalry that The Last of the Mohicans exposes are equally present in Scott's twelfth-century England-or, for that matter, in nineteenth-century society, British or American. Yet Scott does not test chivalry as rigorously as he might, as no men in Ivanhoe are utterly outside its sexual economy. I am proposing that savage Indians like Cora's murderer are not simply Cooper's motive for revising Scott in the ways I have described; they are also, on another plane, a device 
by means of which he revises him. Cooper has a second motive: the Indians are his way of putting on trial the trust in chivalry that Scott cannot fully disown, and for Cooper such a trial by itself would be incentive enough. This second motive originated in the tensions within chivalry that contemporary discourse repeatedly dramatized and, ultimately, could not resolve.

Cleveland State University 